Ta'dib: Journal of Islamic Education

Volume 21, Number 1, June 2016

\title{
The Effect of Multiple Intelligence-Based Instruction on Critical Thinking of Full Day Islamic Elementary Schools Students
}

\author{
Alhamuddin \\ Faculty of Tarbiyah and Teaching \\ Islamic University of Bandung, Indonesia \\ E-mail: alhamuddinpalembang@gmail.com
}

\section{Bukhori}

Faculty of Tarbiyah and Teaching

Sultan Syarif Kasim State Islamic University of Riau, Indonesia

E-mail: bukhori@uin-suska.ac.id

\begin{tabular}{l|l|l}
\hline Received: $30^{\text {th }}$ May 2016 & Revised: $5^{\text {th }}$ June 2016 & Accepted: $15^{\text {th }}$ June 2016
\end{tabular}

\begin{abstract}
Lack of critical thinking skills of elementary schools' students was influenced by teachers' domination in instructional activities; meanwhile students did not play independently as the learners. Theoretically, multiple intelligences based instruction is an appropriate solution. For that reason, this research aims to know the impact of multiple intelligences based instruction on students' critical thinking skills. The research was conducted at AlAmanah and Buahati Islamic Elementary Schools by using a quantitative approach with case study method. Data collected through critical thinking tests was analyzed by using independent sample t-test to examine the impact of instruction on students' critical thinking skills. The results showed that the implementation of multiple intelligences based intruction had significant effect on students' critical thinking skills. From the finding, some recommendations are given as follows: 1) The teacher's role is not only for transferring knowledge based on his/her competencies but also students' characteristics reflecting their instruction styles; and 2) for further researcher, it is suggested to investigate this issues more specifically and comprehensively.
\end{abstract}

Keywords: Multiple Intelligences, Instruction, Critical Thinking

\begin{abstract}
Abstrak
Kurangnya keterampilan berpikir kritis dari siswa sekolah dasar dipengaruhi oleh dominasi guru dalam kegiatan pembelajaran; Sementara itu siswa tidak bermain secara independen sebagai peserta didik. Secara teoritis, pendekatan berbasis kecerdasan ganda merupakan solusi yang tepat. Untuk itu, penelitian ini bertujuan untuk mengetahui dampak pendekatan berbasis kecerdasan ganda pada keterampilan berpikir kritis siswa. Penelitian ini dilakukan di Sekolah Dasar Islam Al-Amanah dan Buahati dengan menggunakan pendekatan kuantitatif dengan metode studi kasus. Data dikumpulkan melalui tes berpikir kritis dianalisis dengan menggunakan sampel independent t-test untuk menguji dampak dari pendekatan pada keterampilan berpikir kritis siswa. Hasil penelitian menunjukkan bahwa pelaksanaan pendekatan berbasis kecerdasan ganda memiliki dampak yang signifikan terhadap kemampuan berpikir kritis siswa. Dari temuan tersebut, beberapa rekomendasi yang diberikan sebagai berikut: 1) Peran guru tidak hanya untuk mentransfer pengetahuan berdasarkan kompetensinya, tapi juga karakteristik siswa mencerminkan gaya pendekatan mereka; dan 2) bagi peneliti selanjutnya, disarankan untuk menyelidiki ini secara lebih spesifik dan komprehensif.
\end{abstract}

Kata Kunci: Kecerdasan Ganda, Pengajaran, Berpikir Kritis

\section{Introduction}

Essentially, the instruction is the process of thinking, not only emphasize on accumulated knowledge of the subject matter, but also concern on the ability of student to acquire knowledge (self-regulated) (Sanjaya, 2008; Rose \& Nicoln, 2001). The result of 
research showed that practically instruction in primary schools in Indonesia still ignore the students' thinking skills (Widuroyekti, 2006; Rustini, 2008; Semiawan, 1999), as the result "student's thinking skill in elementary school are still very poor". It occurs since the teachers do not understand the fundamentals of thinking well wherein students are only required to know, understand and use, and not being able to cultivate the ability of analysis, synthesis, and evaluation (Rofi'uddin, 2000).

The research result above indicates that the instruction is not only limited to the purpose to find, understand and use, but also being able to cultivate the ability of analysis, synthesis, and evaluation. Three of these domains are classified by Bloom as a critical thinking skill (Duron et al, 2006: 160). Therefore, teachers are required to create an instructional environment that can stimulate students to think.

Islamic education as one of the compulsory subjects at every level of education still has some weaknesses in which the role of instruction of Islamic education has not been ideal. The result of study showed that in general the weaknesses placed in the instruction process trapped in the process of memorization and development of low-level thinking skills Azizy (in Shukri, 2003: 237). This fact implies the necessity of improvement by changing instruction paradigm of Islamic education. One form of new innovations in the world of education is the application of the theory of multiple intelligences in instruction. The theory of multiple intelligences capable of bridging the tedious process of instruction into a fun instruction experience and the students are not only overwhelmed by the mere theory, but also They are faced with the fact that the theory that they receive is to be found in real life, so that they have a deep impression. Hence, there is a need to research this area to obtain broader picture of the impact of multiple intelligence based instruction on students' critical thinking in Islamic education subject. Therefore, this study covers the research questions: is there any significant difference of students' critical thinking between those taught by using multiple intelligence based instruction and those who did not.

\section{Literature Review}

Multiple Intelligences

Multiple intelligences are a recent development in the field of intelligence that explains things related to the pathways used by humans to be intelligent. This discovery changed the paradigm in education including a new understanding for students and parents that the child's intelligence is extremely diverse. According to Gardner (1993: 15) theory of multiple intelligences emphasizes on "the ability to solve problems and to create a product or work that can be useful to others". This theory was introduced by Howard Gardner in the early decades of the 1983's (Gardner, 1983, 1993, 1999; Armstrong, 2009; Campbel, Campbel, \& Dickinson, 1995; Hoerr, 1999; Baum, 2005) "Intelligences entail the ability to solve problems or fashion product that are of consequence in a particular cultural setting or community. The problem-solving skill allows. One to approach situation in which a goal is to be obtained and to locate the appropriate route to that goal".

The main concepts of this theory are: (1) humans have the ability to improve and develop their intelligent; (2) intelligence in addition to change can also be taught to others; (3) intelligence is a pluralistic reality that appear in different parts of the system or the brain of the human mind; (4) at a certain level, that intelligence is a unified whole, 
The Effect of Multiple Intelligence-Based Instruction

on Critical Thinking of Full Day Islamic Elementary School Students

Alhamuddin dan Bukhori

meaning in solving a specific problem or task, all kinds of human intelligence work together.

Departing from the concepts above, then, Gardner (1993: 17-25) maps the broad scope of human capabilities into nine categories of comprehensive or "basic intelligence" namely; musical intelligence, kinesthetic intelligence-gestures, intelligence mathematical logic, linguistic, spatial, interpersonal, intrapersonal, naturalist and existential. The theory is based on the premise that intellectual ability is not only measured by math and language abilities, but also to be seen from some other intelligence.

In the concept of multiple intelligences based instruction learners are functioned as a creative and innovative subjects. Students are given the freedom to develop the full potential of intelligence optimally, through instruction strategies tailored to the student's instruction style and support activities. It is applied through interactive teaching and instruction activities, interesting, stimulating both hemispheres learners in a balanced way, paying attention to the uniqueness of each individual, and involving the active participation of learners. As the result, the whole potential of learners develops optimally. In addition, instruction in a variety of activities are designed to increase knowledge (cognitive), attitudes (affective), and skills (psychomotor) to integrate and facilitate the development of a variety of intelligence plural owned learners (Baum, 2005:37; McKenzie, 2005; Fleetham, 2006:87; Armstrong, 2009:44; Yaumi, 2012: Jasmine, 2012, Alhamuddin, 2016).

Previous research such as Campbell and Campbell (2000), in book "Multiple Intelligences and Student Achievement; Sucsess Stories from Six Schools”, described six schools that have used multiple intelligences for five or more years. Through case studies of two elementary, two-middle level, and two high schools. This research was conducted in Kentucky, Minnesota, Washington, Indiana, dan California. Hoerr (2000), in his book "Becoming Multiple Intelligences School", elaborate the process passes alongside colleagues in implementing the principles of multiple intelligences theory in New City School di St.Louis, Misouri. The results showed that the increase in test scores, discipline, parent participation is greater, and students labeled learning disabled.

Jingcen Xie dan Ruilin Lin (2009) "Research on Multiple Intelligences Teaching and Assessment", Ozlen Dogan Temur (2007) "The Effects of Teaching Activities Prepared According to the Multiple Intelligences Theory on Mathematics Achievements and Permanent of Information learned by $4^{\text {th }}$ Grade Students". Test of effectiveness of learning between groups using multiple intelligences as a delivery strategy with the group using traditional methods. The researchers concluded that students who are taught by multiple intelligences have better results than students taught by traditional methods. In addition, students actively participate in the learning process, increases learning interest and learners more aware of their capabilities.

Ali Abdi dan Maryam Rostami (2012) “ The Effect Multiple Intelligences-Based Instruction on Students' Creative Think ability at 5th grade in Primary School”. This study was conducted to test the effect of multiple intelligences based instruction to creative thinking abilities of learners. The study results concluded that the multiple intelligences can improve creative thinking skills of learners. The results of this study support the results of previous research of Boyd Sturthers (2008) and Heyns (2007). 


\section{Critical Thinking}

Thinking is "a person's mental processes that are more than just recall (remembering) and understanding (comprehending)" (Peter Reason in Sanjaya, 2008: 132). According to Reason remember and understand more passive than the activity of thinking. Remembering only involves the storage of something that has been experienced for a while reissued upon request, while understanding requires the acquisition of what is heard and read and look at the relationship between aspects of memory. Thinking is a term that is more than two. Thinking causes a person to move to outside information heard. Thinking skills require ability to remember and understand, therefore, the ability to remember is the most important part in developing critical thinking. Someone who has the ability to remember and understand has also the ability to think. Instead ability to think someone has definitely followed the ability to remember and understand (Sanjaya, 2008: 132). Thus, thinking as activities that involve mental processes require the ability to remember and understand, on the contrary to be able to remember and understand the necessary mental process called thinking. "Thinking is an internal, mental process that constructs and operates on mental representation of information" (Craik, 1943: Zangwill, 1980; Nathan, 1987 dalam Moseley et al. 2005).

Furthermore, experts divide thinking skills into three, namely: basic thinking skills, critical thinking, and creative thinking. Critical thinking is a process that involves mental operations such as induction, deduction, classification, and reasoning. Ethnic (in Fisher, 2001: 4), "critical thinking is reasonable. Reflective thinking that is focused on deciding what to believe or do". According to Ibrahim and Nur (2000: 25) "the process of thinking covers activities of analyzing, criticizing, and reaching conclusions based on inference or careful consideration". In line with these opinions, Angelo (1995: 6) states that "critical thinking must meet the characteristics of thinking activities which include: analysis, synthesis, problem recognition and solving, conclusions and judgments". Thus, it is understood that critical thinking is one of the higher-level thinking processes that can be used in the formation of students' conceptual.

Furthermore, McMurry et al (1991:15), states that critical thinking is an activity that is very important to be developed in the school. Teachers are expected to be able to realize instruction skills and develop students' critical thinking. This ability cannot grow automatically through the development of person's age. This capability will develop well if deliberately developed. Glaser (in Fisher, 2001: 3) states the consideration of critical thinking, namely: a) An attitude of being disposed to consider in a thoughtful way the problems and subjects that come within the range of one's experience; 2) knowledge of the methods of logical enquiry and reasoning; and 3) some skill in applying those methods. Critical thinking calls for a persistent effort to examine any belief or supposed from of knowledge in the light of the evidence that support it and the further conclusion to which it tends.

There are some essential points that can be explained from Glaser point of view wherein critical thinking was not only present an attitude of willingness to consider something in solving the problem, but also must be done through the process of thinking and considering. Similarly, knowledge of the methods of investigation and logical reasoning shows that the critical thinking is required in their understanding of scientific methods and rational to produce something. John Dewey (1909: 9; Fisher, 2001: 2), 
The Effect of Multiple Intelligence-Based Instruction

on Critical Thinking of Full Day Islamic Elementary School Students

Alhamuddin dan Bukhori

considers that "critical thinking that is reflective thinking". Dewey emphasizes critical thinking in an active process, the assurance that a strong and carefully, and ground support roommates (rationale that supports) something that can be inferred. That is, the foundation of thinking must be based on rational reasons and implications must be examined from the standpoint. "Active, persistent, and careful consideration of a belief or supposed from of knowledge in the light of the grounds which aupport it and the further conclusion to which it tends". Meanwhile, Ricard Paul as cited in Fisher (2001:4) states: "Critical thinking is thinking about thinking itself, or often referred to meta-cognition". In other words critical thinking is meta-cognition. "Critical thinking is mode of thinking-about any subject, content or problem in which the thinkers improve the quality of his or her thinking by skillfully taking charge of the structures inherent in thinking and imposing intellectual standards upon them".

Hilsdon (2009:1-9), formulated indicators of critical thinking skills with a simple pattern, namely the ability to describe, analyze, and evaluate the concept of something or something else. The Hilsdon Opinions illustrated in the table 1 below.

Table 1: Indicators of Critical Thinking Skills

\begin{tabular}{|c|c|c|c|}
\hline No & Indicator & Questions & Sample Questions \\
\hline \multirow{4}{*}{1} & \multirow{4}{*}{ Description } & What & $\begin{array}{l}\text { What is this about? } \\
\text { What is this context/ situation? } \\
\text { What is the main point/problem /topic to be } \\
\text { explored? }\end{array}$ \\
\hline & & Where & Where does it take place? \\
\hline & & Who & $\begin{array}{l}\text { Who is this by? } \\
\text { Who is involved? } \\
\text { Who is affected? } \\
\text { Who might be interested? }\end{array}$ \\
\hline & & When & When does this occur? \\
\hline \multirow{3}{*}{2} & \multirow{3}{*}{ Analysis } & How & $\begin{array}{l}\text { How did this occur? } \\
\text { How does it work -in theory? } \\
\text { How does one factor affect another? Or } \\
\text { How do the parts fit into the whole? }\end{array}$ \\
\hline & & Why & $\begin{array}{l}\text { Why did this occur? } \\
\text { Why was that done? } \\
\text { Why this argument/theory /suggestion } \\
\text { /solution? } \\
\text { Why not something else? }\end{array}$ \\
\hline & & What if & $\begin{array}{l}\text { What if this wrong? } \\
\text { What are the alternatives? } \\
\text { What if there were problems? } \\
\text { What if this or that factor were-added? } \\
\text { Removed? Altered? }\end{array}$ \\
\hline 3 & Evaluation & So what & $\begin{array}{l}\text { What does mean? } \\
\text { Why is this significant? } \\
\text { Is this convincing? Why/why not? } \\
\text { What are the implications? } \\
\text { Is it successful? } \\
\text { How does it meet the criteria? } \\
\text { It is transferable? }\end{array}$ \\
\hline
\end{tabular}




\begin{tabular}{|l|l|l|}
\hline & What next & $\begin{array}{l}\text { How and where else can be applied? } \\
\text { What can be learning from it? } \\
\text { What needs doing now? }\end{array}$ \\
\hline
\end{tabular}

Source: Hilsdon (2009:1-9)

Based on the above three indicators, the ability to describe, analyze and evaluate as an indicator of a person can be considered to have critical thinking skills.

\section{Research Methodology}

This study used a quantitative approach with causal comparative research since both the effect and the alleged cause have already occurred and must be studied in retrospect (Gay, 2000; Cohen, Manion, \& Morrison, 2007; Gal, Gal \& Borg, 2003; see also Tuckman, 1978; Ary, Jacobs \& Razavieh, 1985, 2010; Lodico, Spaulding \& Voegtle, 2006; Fraenkel, Wallen \& Hyun, 2012). The research was conducted at Al-Amanah Islamic Elementary School Bandung and Buahati Islamic Elementary School Jakarta, in academic year 2013/2014. This study involved students of class five as the sample. Data collected through tests of critical thinking were analyzed by using independent sample ttest.

\section{Research Finding and Discussion}

Hypothesis testing is done with inferential statistics to determine whether the proposed research hypothesis is accepted or otherwise rejected at a certain significance level (in this study using $\alpha=0.05$ ). The hypothesis of this study is "there is a difference between instruction critical thinking skills-based PAI multiple intelligences and the traditional method". The results are illustrated in the table 2 below.

Table 2: Group Statistic

\begin{tabular}{|c|c|c|c|c|c|}
\hline & Approach & $\mathrm{N}$ & Mean & $\begin{array}{c}\text { Std. } \\
\text { Deviation }\end{array}$ & $\begin{array}{c}\text { Std. Error } \\
\text { Mean }\end{array}$ \\
\hline $\begin{array}{c}\text { Critical } \\
\text { thinking }\end{array}$ & $\begin{array}{c}\text { Multiple } \\
\text { Intelligence } \\
\text { Non Multiple } \\
\text { Intelligence }\end{array}$ & 85 & 25.6353 & 3.75070 & .40682 \\
\hline
\end{tabular}

The table shows that the mean score of control group was around 22.0556 and experimental group was 25.6353. Based on the data, there are relatively slight differences of critical thinking skill between the two groups. In order to understand the initial condition of the groups thoroughly it is needed for further analysis by comparing mean statistically as described in the following table. 
The Effect of Multiple Intelligence-Based Instruction

on Critical Thinking of Full Day Islamic Elementary School Students

Alhamuddin dan Bukhori

Table 3: Result of t-Test

\begin{tabular}{|c|c|c|c|c|c|c|c|c|c|}
\hline & \multicolumn{2}{|c|}{$\begin{array}{c}\text { Levene's } \\
\text { Test for } \\
\text { Equality of } \\
\text { Variances }\end{array}$} & \multicolumn{7}{|c|}{ t-test for Equality of Means } \\
\hline & \multirow[t]{2}{*}{$\mathrm{F}$} & \multirow[t]{2}{*}{ Sig. } & \multirow[t]{2}{*}{$\mathrm{T}$} & \multirow[t]{2}{*}{ df } & \multirow[t]{2}{*}{$\begin{array}{l}\text { Sig. (2- } \\
\text { tailed) }\end{array}$} & \multirow[t]{2}{*}{$\begin{array}{l}\text { Mean } \\
\text { Differe } \\
\text { nce }\end{array}$} & \multirow{2}{*}{$\begin{array}{c}\text { Std. } \\
\text { Error } \\
\text { Differe } \\
\text { nce }\end{array}$} & \multicolumn{2}{|c|}{$\begin{array}{l}\text { 95\% Confidence } \\
\text { Interval of the } \\
\text { Difference }\end{array}$} \\
\hline & & & & & & & & Lower & Upper \\
\hline $\begin{array}{l}\text { Equal } \\
\text { variances } \\
\text { assumed } \\
\text { Equal } \\
\text { variances } \\
\text { not } \\
\text { assumed }\end{array}$ & $\begin{array}{c}11.6 \\
94\end{array}$ & .001 & $\begin{array}{r}4.3 \\
64 \\
\\
3.9 \\
62\end{array}$ & $\begin{array}{l}80 . \\
112\end{array}$ & .000 & 3.57974 & .82035 & 1.78167 & $\begin{array}{c}5.2019 \\
3 \\
\\
5.3778 \\
1\end{array}$ \\
\hline
\end{tabular}

Table 3 showed that the Sig-( 2 tailed) are smaller than $\alpha=0.05$. Hence, it can be concluded that there is a significant difference of critical thinking skills between the students who were treated by using multiple intelligences and those who obtained conventional approach in instructions of Islamic education. It means that the use of multiple intelligences based instruction provides positive effect on students' critical thinking in Indonesian Islamic elementary schools.

This finding support the results of previous studies conducted by Abdi (2012), Coban (2011), Boyd-Sturters (2008), Heyns (2007) which states that multiple intelligences based instruction beneficial to learners to enhance the ability to think. It is reasonable since multiple intelligences based instruction emphasizes the activity, where students not only as executor of instruction provided by educators, but also acts as an agent of cognitive process distributed between educators and learners (Yaumi, 2012: 32). In other words, the instruction activities refer to the education system in facilitating learners to become agents of change through experience, knowledge, skills and abilities, to obtain a method for selfinstruction and to develop multiple intelligences of learners.

Based on the above findings and discussion, the instruction process for preparing learners with the critical thinking skills demanded readiness of teachers in planning, implementing, and evaluating instruction. The teacher plays a central role as a facilitator of instruction. Learners are facilitated to proceed to master teaching materials with a variety of instruction resources prepared. Teachers is charge of guarding the process takes place within the framework of mastery of the competency, although learner-centered instruction. According to the constructivism theory: "learning is more determined by the wills of individuals" (Budiningsih, 2005: 5). Arrangement of conditions is not the cause of instruction, but simply facilitates instruction. Active learners become a very important element in determining the success of instruction. Independent activity is a guarantee to achieve real results.

In addition, students in multiple intelligences classroom have high hope and expectation for themselves and had a significantly influence students to create positive self-fulfilling prophecies. Campbell (1999) said "multiple intelligences not only make a 
positive difference in educational programs, it improves the lives of children".

\section{Conclusion}

Finally, the findings indicate that the implementation of multiple intelligences based intruction had significant contribution in improving student's critical thinking skills. Based on the conducted research, some recommendations are given as follows: 1) The teacher's role does not only transfer knowledge based on his/her competencies but students' characteristics also reflect in their instruction styles; and 2) for further researcher, it is suggested to investigate this issues more specific and comprehensive. 
The Effect of Multiple Intelligence-Based Instruction

on Critical Thinking of Full Day Islamic Elementary School Students

Alhamuddin dan Bukhori

\section{Refferences}

Alhamuddin. (2016). Desain Pembelajaran untuk Mengembangkan Kecerdasan Majemuk Siswa Sekolah Dasar. Al-Murabbi, 2(2), 180-201.

Anderson, J.W., Krathwol, D.R. (2001). A Taxanomy in Instruction, Teaching, Assessing. A Revision of Bloom. 's Taxonomy of Educational Objectives. New York. Longman.

Angelo, T.A. (1995). Begining the Dialogue: Thoughts on Promoting Critical Thinking; Classroom Assessment for Critical Thinking. Teaching of Psycology. 22 (1). Hal. 67.

Armstrong, T. (2009). Multiple Intelligences in the Classroom: $3^{\text {rd }}$ edition. Virginia. ASCD.

Baum, S., Viens, J., \& Slatin, B. (2005). Multiple Intelligences in the Elementary Classroom. New York. Teacher College, Columbia University.

Beyer, B. K. (1993). Teaching Thinking Skills; a Handbook for Elementary School Teachers. Boston. Allyn and Bacon.

Bloom, B. S. (1956). Taxonomy of Education Objective. New York. David McKaY.

Campbell, L. (1997). Variations on a theme-How Teachers Interpret MI Theory. Educational Leadership. 55 (1).

Campbell, L \& Campbell, B.. (1999). Multiple Intelligences and Student Achievement; Success Stories from Six Schools. Virginia. ASCD.

Collins, C., \& Mangieri, J.N. (1992). Teaching Thinking; an Agenda for Twenty-First Century. Hilsdale, NJ. Laurance Erlbraum Associates Publishers.

Duron, R., et al. (2006). Critical Thinking Framework for Any Discipline. International Journal of Teaching and Instruction in Higher Education. 17. Hal. 160-166.

Emis, R.H. (1985). A Logical Basis for Measuring Critical Thinking Skills. Education Leadership. 43 (2). Hal. 44-48.

Fisher, A. (2001). Critical Thinking; an Introduction. Cambridge. Cambridge University Press.

Fleetham, M. (2006). Multiple Intelligences in Practice Enhancing Self-Esteem and Instruction in the Classroom. Stafford. Network Continum Education.

Gardner, H. (1993a). Frames of Mind; The Theory of Multiple Intelligences-10 ${ }^{\text {th }}$ anniversary edition. New York. Basic Books.

(1993b). Multiple Intelligences. The Theory in Practice. New York. Basic Books.

Glaser, E. (1941). An Experiment in the Development of Critical Thinking. Advanced School of Education at Teacher's Colege. Columbia University.

Hasan, H. (1996). Pendidikan IPS Buku 1 dan 2. Bandung. Jurusan Sejarah FPIPS IKIP Bandung.

Hilsdon, J. (2010). Critical Thinking, Improving, Analysis, Argument and Structure in your Assingment. Uk. The University of Plymouth.

Horer, T.R. (2000). Becoming a Multiple Intelligences School. Virginia. ASCD.

Joyce, B., Weil, M., \& Calhoun, E. (2009). Model of Teaching. Boston. Pearson Education Inc.

Killen, R. (1998). Effective Teaching Strategies Lesson from Research and Practice. Australia. Social Science Press. 
Lazear, D.G. (1992). Teaching for Multiple Intelligences. Indiana. Phi Delta Kappa Education Foundation.

Marzano, R.J, et al. (1993). Dimenssion of Thinking; a Frame for Curriculum and Instruction. Alexandria. Association for Supervision and Curriculum Development.

McGregor, D. (2007). Develop[ing Thinking Developing Instruction. A Guide to Thinking Skills in Education. New York. Open University Press.

McKenzie, W. (2005). Multiple Intelligences and Instructional Technology. Washington. International Society for Technology in Education.

Moseley et al. (2005). Framework of Thinking. A Handbook for Teaching and Instruction. Cambridge. Cambridge University Press.

Rofi'uddin, A. (2000). Pengembangan Model Pendidikan Berpikir Kritis-Kreatif untuk Siswa Sekolah Dasar dalam Rangka Peningkatan Kualitas Sumber Daya Manusia. Jakarta. Dewan Riset Nasional RUT IV.

Rose, C \& Nichol, M.J. (2001). Accelerated Instruction for the $21^{\text {st }}$ century (Cara Belajar Cepat Abad XXI). Penerjemahah; Dedi Ahimsa. Bandung. Nuansa Kerjasama dengan Pusat Perbukuan Depdiknas.

Rotherham, A.J., dan Willingham, D. (2009). $21^{\text {st }}$ Century Skills; the Challenges Ahead. Educational Leadership. 67 (1). Hal. 16-21.

Semiawan, C. (1999). Pendidikan Tinggi, Peningkatan Kemampuan Manusia Sepanjang Hayat Seoptimal Mungkin. Jakarta. Depdikbud. Dirjen Dikti.

Stanford, P. (2003). Multiple Intelligences for Every Classroom. Intervention on Social and Clinic. Vol. 39, No 2, pp.80-85.

Strenberg, R.G; Okagaki,1,; and Jackson, A.(1990). Practical Intelligences for Success in School. Educational Ledearship 48. Hal. 35-39.

Sujana, N. (1991). Dasar-Dasar Proses Belajar Mengajar. Bandung. Sinar Baru.

Yaumi, M. (2012). Pembelajaran Berbasis Multiple Intelligences. Jakarta. Dian Rakyat. 